\title{
ANALISIS DAMPAK MAKROEKONOMI terhadap KEUNTUNGAN pada SEKTOR PERBANKAN di BEI
}

\author{
Tetty Tiurma Uli Sipahutar \\ ratuhapis.tetty@gmail.com \\ Program Studi Akuntansi, \\ Fakultas Ekonomi Universitas Prima Indonesia
}

\begin{abstract}
The increasing number of banking institutions in Indonesia is accompanied by an increase in literature studies related to banking institutions. It is important to update the study related to banking developments in Indonesia. This study aims to analyze the influence of the macroeconomy that affects profitability in the banking sector. The sample used in this study is the banking sector which is listed on the Indonesia Stock Exchange (IDX) for the period 2014-2017 totaling 30 banks. The results of the regression analysis showed no significant effect between GDP and inflation on ROE and had a negative direction
\end{abstract}

Keywords: GDP, Inflation, ROE

\begin{abstract}
Abstrak
Meningkatnya jumlah lembaga perbankan di Indonesia dibarengi dengan peningkatan studi literatur terkait dengan lembaga perbankan. Penting untuk memperbarui studi terkait perkembangan perbankan di Indonesia. Penelitian ini bertujuan untuk menganalisis pengaruh ekonomi makro yang mempengaruhi profitabilitas di sektor perbankan. Sampel yang digunakan dalam penelitian ini adalah sektor perbankan yang terdaftar di Bursa Efek Indonesia (BEI) untuk periode 2014-2017 berjumlah 30 bank. Hasil analisis regresi tidak menunjukkan pengaruh yang signifikan antara PDB dan inflasi terhadap ROE dan memiliki arah negatif
\end{abstract}

Kata kunci: PDB, Inflasi, ROE

\section{Pendahuluan}

Industri perbankan sebagai salah satu sektor keuangan yang memiliki peran pendukung utama dalam kegiatan ekonomi di Indonesia (Suryan dkk, 2016). Bank memberikan kontribusi besar bagi perekonomian suatu negara. Sebagai lembaga perantara, bank memiliki peran sebagai saluran untuk pembiayaan, penyimpanan, dan pinjaman sehingga pada akhirnya akan mensejahterakan kehidupan masyarakat. Fungsi perbankan sangat penting, sehingga bank terpaksa menjadi lebih kompetitif dan menerapkan sistem peringkat kesehatan bank (Attar dkk., (2014). Pertumbuhan sektor perbankan mendorong pertumbuhan produk perbankan, dan semakin banyak bank yang menjangkau masyarakat. 


\section{Akuntansi Prima \\ Vol 10 No 1, 2020}

Kinerja keuangan bank memiliki implikasi penting bagi pertumbuhan ekonomi suatu negara yang dapat dilihat dari laporan keuangannya. Menurut Taswan, (2010), laporan keuangan bank dimaksudkan untuk memberikan informasi berkala tentang keseluruhan kondisi bank, termasuk pengembangan bisnis dan kinerja bank. Kinerja keuangan bank yang baik merupakan apresiasi bagi pemegang saham atas investasi. Aktivitas ekonomi tidak dapat dipisahkan dari pengaruh ekonomi makro. Inflasi, nilai tukar, harga minyak dunia, dan BI-Rate adalah variabel independen yang bergerak untuk mempengaruhi kinerja perbankan.

Pertumbuhan ekonomi (PDB) suatu negara erat kaitannya dengan kesejahteraan dan kemakmuran yang bisa dirasakan oleh penduduk negara itu. Tingkat pendapatan yang diukur dengan PDB akan mempengaruhi pola tabungan seseorang, semakin besar PDB, profitabilitas bank juga akan meningkat. Bodie, (2014), menyatakan bahwa ada beberapa variabel ekonomi makro yang dapat digunakan oleh analis yang ingin melakukan investasi untuk menilai kondisi ekonomi makro yaitu PDB, lapangan kerja, inflasi, suku bunga, nilai tukar, transaksi berjalan, dan defisit anggaran.

Variabel makro secara signifikan memiliki dampak langsung pada lembaga keuangan, terutama bank. Seperti inflasi dalam teori disebutkan bahwa kinerja keuangan bank banyak dipengaruhi oleh inflasi.

\section{e-ISSN: $2088-6136$}

Ketika inflasi terjadi, orang cenderung memilih lembaga keuangan untuk melakukan kegiatan menabung karena dalam kondisi ini bank akan menawarkan suku bunga tinggi. Sebagai perantara, bank sangat dekat dengan masalah yang terkait dengan stabilitas modal. Ketika harga tumbuh dengan cepat, orang-orang akan kewalahan oleh harga bahan di pasar untuk memenuhi kebutuhan sehari-hari. Bagi suatu perusahaan, terjadinya inflasi juga dapat mengakibatkan peningkatan biaya produksi atau biaya operasional, sehingga ini dapat membuat perusahaan perbankan mengalami kerugian. Inflasi juga dapat menciptakan suku bunga tinggi. Di sisi lain, meningkatnya bunga kredit dapat menjadi penghalang kredit.

Dalam penelitiannya Riaz, (2013), ditemukan faktor-faktor yang mempengaruhi profitabilitas, yaitu faktor internal dan makroekonomi. Faktor ekonomi makro yang mempengaruhi profitabilitas adalah tingkat bunga. Ogunbiyi \& Ihejirika, (2014) profitabilitas sektor perbankan merupakan fungsi dari perubahan suku bunga. Masalah profitabilitas bagi bank merupakan masalah penting karena profitabilitas bank adalah target utama yang harus dicapai. Profitabilitas adalah kunci utama untuk mendukung keberlanjutan dan pengembangan bank yang bersangkutan. Semakin tinggi tingkat profitabilitas, semakin baik kinerja perbankan. Pemberian profitabilitas sebagai indikator 
kinerja perusahaan adalah fokus utama dari laporan keuangan modern. Melihat dan memahami pentingnya profitabilitas bank sebagai tujuan utama sebuah bank, harus dipertimbangkan secara serius dalam kinerja profitabilitasnya. Rasio profitabilitas memiliki peran penting dalam mengukur kinerja keuangan bank. Pada dasarnya, semua kegiatan operasional perusahaan akan menghasilkan laba operasi.

Banyak peneliti percaya bahwa variabel ekonomi makro, seperti tingkat inflasi yang tinggi (Garmendia, 2012), menyebabkan perusahaan mengalami kesulitan keuangan yang berdampak pada menurunnya kinerja keuangan. perusahaan.

Tujuan dari penelitian ini adalah untuk menganalisis pengaruh signifikan antara PDB, dan Inflasi terhadap Profitabilitas Sektor Perbankan yang terdaftar di Bursa Efek Indonesia (BEI) untuk periode 2014-2017.

\section{Tinjauan Literatur \\ Bank}

Taswan, (2010) menjelaskan bahwa bank adalah lembaga atau perusahaan yang kegiatannya mengumpulkan dana dalam bentuk giro, tabungan dan simpanan lain dari pengeluaran berlebih (unit pengeluaran surplus) dan kemudian mengembalikannya kepada orangorang yang membutuhkan dana (unit pengeluaran defisit) melalui penjualan jasa keuangan yang pada gilirannya dapat meningkatkan kesejahteraan banyak orang. Kinerja bank secara eksplisit diwakili oleh rasio, meskipun tidak dapat dipungkiri bahwa pada akhirnya bank akan dinilai untuk kesehatan. Selain itu, bank komersial memainkan peran penting dalam pertumbuhan ekonomi negara. Melalui intermediasinya, fungsi bank memainkan peran penting dalam alokasi sumber daya yang efisien dari negara-negara dengan memobilisasi sumber daya untuk kegiatan produktif.

\section{Tingkat Pertumbuhan Ekonomi}

Produk Domestik Bruto (PDB) adalah salah satu indikator ekonomi makro yang paling umum digunakan untuk mengukur total kegiatan ekonomi, yang dapat mempengaruhi berbagai faktor baik dalam permintaan maupun pasokan layanan perbankan. Makroekonomi adalah bagian dari ekonomi yang berspesialisasi dalam mempelajari mekanisme operasi ekonomi secara keseluruhan, yang bertujuan untuk memahami peristiwa atau fenomena ekonomi dan untuk meningkatkan kebijakan ekonomi. (Putong, 2015).

Sukirno, (2011) berpandangan bahwa pertumbuhan ekonomi adalah perkembangan kegiatan dalam perekonomian yang menyebabkan barang dan jasa yang diproduksi di masyarakat meningkat karena peningkatan pendapatan masyarakat. Data yang digunakan untuk mengukur pertumbuhan ekonomi suatu negara adalah dengan 


\section{Akuntansi Prima \\ Vol 10 No 1, 2020}

menghitung pendapatan nasional riil atau Produk Domestik Bruto (PDB) menurut harga tetap (harga yang berlaku di tahun dasar) yang berlaku dari tahun ke tahun. Tingkat pertumbuhan ekonomi menurut harga tetap dapat dihitung dengan rumus:

$$
\begin{aligned}
& \text { Tingkat Pertumbuhan Ekonomi } \\
& =\frac{P D B_{t}-P D B_{t-1} x 100 \% \mathrm{~T}}{P D B_{t-1}}
\end{aligned}
$$

Peningkatan pendapatan masyarakat menghasilkan peningkatan konsumsi dan tabungan masyarakat sehingga ketika pertumbuhan ekonomi ditandai dengan peningkatan pendapatan masyarakat, profitabilitas bank dapat meningkat karena tabungan yang mendorong bank untuk meningkatkan alokasi dana melalui kredit.

\section{Inflasi}

Teori Keynes menjelaskan inflasi dapat bekerja karena disebabkan oleh kelompok orang yang ingin hidup lebih dari batas kapasitas ekonomi. Ini mengakibatkan pengeluaran publik lebih banyak untuk konsumsi daripada menabung di bank. Sehingga orang akan menarik uang yang sebelumnya disimpan di bank. Penarikan uang mengakibatkan JUB meningkatkan jumlah orang di komunitas, yang pada gilirannya akan menyebabkan inflasi dan ketidaksetaraan. Sejauh kesenjangan ini ada, inflasi adalah sama.

Inflasi adalah kecenderungan harga naik secara umum dan terus menerus. Kenaikan harga hanya satu

\section{e-ISSN: 2088-6136}

atau dua barang tidak disebut inflasi, kecuali jika kenaikan meluas ke sebagian besar harga barang lainnya. (Putong, 2015).

(Hasan dkk., (2013) mengatakan bahwa Inflasi Harga Konsumen (IHK) adalah tingkat inflasi. CPI adalah salah satu faktor ekonomi makro yang dapat mempengaruhi ROE bank. Keuntungan bank dapat secara langsung dipengaruhi oleh tingkat inflasi karena akan mengubah tingkat bunga pinjaman serta CPI tidak signifikan secara statistik dalam menjelaskan ROE.

Alper, (2017) mengungkapkan bahwa CPI mengukur persentase kenaikan secara keseluruhan dalam Indeks Harga Konsumen (CPI) untuk semua barang dan jasa.

Peningkatan harga inflasi terjadi dari periode ke periode berikutnya dan tingkat kenaikan bervariasi dari satu daerah ke daerah lainnya. Peningkatan harga barang dalam inflasi terjadi pada semua barang yang telah ditentukan, tidak hanya terjadi dalam satu atau dua item. Jadi, jika kenaikan hanya terjadi dalam satu atau dua item maka itu tidak disebut inflasi (Sukirno, 2011).

Menurut Natsir, (2014) rumus yang digunakan untuk menghitung inflasi adalah:

$$
I N F_{n}=\frac{I H K_{n}-I H K_{n-1}}{I H K_{n-1}} x 100 \%
$$

\section{Profitabilitas}

Ada juga faktor yang mempengaruhi profitabilitas menurut Riaz, (2013), yaitu Ukuran Aset, Risiko Kredit, Total Simpanan 
terhadap Total Aset, dan Suku Bunga.

Gitman, (2015), profitabilitas adalah kemampuan suatu perusahaan untuk menghasilkan laba. Perusahaan yang memiliki laba besar akan menjadi incaran investor. Investor tentu akan menginvestasikan dananya di perusahaan dengan laba yang besar untuk mendapatkan keuntungan dari dana yang diinvestasikan. Di sektor perbankan, profitabilitas digunakan untuk mengukur kinerja bank. Profitabilitas adalah pertahanan utama bank terhadap kerugian yang tidak terduga, seperti memperkuat posisi modal dan meningkatkan profitabilitas masa depan melalui investasi pada laba ditahan. Menurut Taswan, (2010), pengukuran profitabilitas di bank adalah:

a. Return on Asset (ROA)

Gitman, (2015) mengatakan bahwa Return on Asset (ROA) digunakan untuk mengukur efektivitas manajemen dalam menghasilkan laba dengan aset yang tersedia. Sering disebut sebagai Pengembalian Investasi (ROI). Jika nilai ROA tinggi, maka perusahaan dikatakan baik. Menurut Obamuyi, (2013), Return on Asset (ROA) adalah rasio keuangan yang digunakan untuk mengukur hubungan pendapatan dengan total aset. Di mana perhitungan profitabilitas, yaitu: (Riaz, 2013)

$$
\text { Return on Assets }=\frac{\text { Net Profit }}{\text { Total Assets }}
$$

b. Return on Equity (ROE)
Gitman, (2015) mengatakan bahwa Return on Equity (ROE) adalah ukuran dari pengembalian yang diperoleh dari investasi pemegang saham biasa di perusahaan. Secara umum, pemegang saham mengharapkan pengembalian investasi yang tinggi. Di mana perhitungan profitabilitas, yaitu: (Riaz, 2013)

$$
\begin{array}{ll}
\text { Return on Equity } & \text { Net Profit } \\
\frac{\text { Stackholders Equity }}{} &
\end{array}
$$

\section{Hipotesis Penelitian}

Berdasarkan variabel yang terkandung dalam penelitian ini, penulis menetapkan hipotesis, yaitu:

H1: Ada pengaruh yang signifikan antara Pertumbuhan Ekonomi terhadap profitabilitas (ROE)

$\mathrm{H} 2$ : Ada pengaruh yang signifikan antara inflasi terhadap profitabilitas (ROE)

H3: Ada pengaruh signifikan terhadap Pertumbuhan Ekonomi dan Inflasi terhadap profitabilitas (ROE)

\section{Metodologi Penelitian}

Metode penelitian yang digunakan dalam penelitian ini adalah pengujian hipotesis. Dengan tujuan untuk mengetahui pengaruh faktor internal makroekonomi terhadap profitabilitas bank. Subjek analisis dalam penelitian ini adalah sektor perbankan yang terdaftar di Bursa Efek Indonesia (BEI) dan memiliki laporan keuangan lengkap sesuai dengan data yang dibutuhkan dari 2014-2017. 
Penelitian ini adalah deskriptif Descriptive Statistics

\begin{tabular}{l|c|c|c|c|c|c} 
kuantitatif. Teknik analisis & data yang & $\mathrm{N}$ & Minimum & Maximum & Mean & Std. Deviation \\
\hline digunakan adalah regr & PSB linier & 120 & 502.856 .200 & 639.830 & 567.307 .225 & 51.351 .262 .010 \\
berganda, sebelum persamalnFLASI & 120 & 3.02 & 8.36 & 4.5850 & 2.19868 \\
Ren model & 120 & .01 & .68 & .0902 & .07541 \\
\hline ROE & &
\end{tabular}

regresi dibentuk, uji asumsi llasik meliputi uji normalitas data, uji autokorelasi, uji multikolinieritas, dan uji heteroskedastisitas. Setelah 24 Sumber: Data diproses dengan SPSS

semua uji asumsi klasi k terpenuhi, Tabel 2 Hasil Regresi langkah selanjutny Modehlah menentukan koefisien determinasi $\left(\mathrm{R}^{2}\right)$ dan menguji perkembangan hipotesis, yaitu uji F dah uj (-Constan digunakan untuk meng hii pergarake

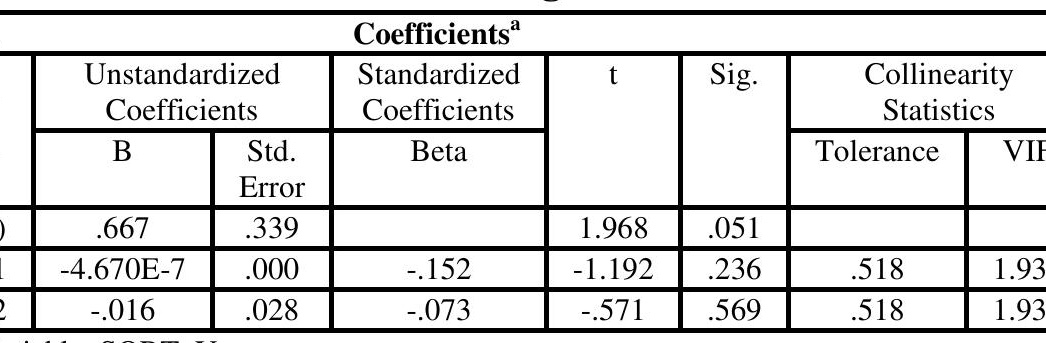
variabel independen a. Dęernderiable: SQRT_Y variabel dependen secara bersamaan. Sedangkan uji-t digunakan untuk menguji pengaruh variabel independen terhadap variabel dependen secara parsial (Widyaningrum \& Siswantoro, 2015).

Rumus dalam menguji data regresi linier berganda adalah sebagai berikut (Widarjono, 2013):

$$
Y=\beta_{0}+\beta_{1} X_{1 t}+\beta_{2} X_{2 t}+e_{t}
$$

Keterangan:

$\begin{array}{ll}Y & =\text { ROE (Return On } \\ \text { Equity) } & \\ \beta_{0}, \beta_{1}, \beta_{2} & =\text { Koefisien Regresi } \\ X_{1} & =\quad \text { PDB } \quad \text { (Produk } \\ \text { Domestik Bruto) } & \\ X_{2} & =\text { Inflasi } \\ e & =\text { Error }\end{array}$

\section{Hasil Penelitian}

Tabel 1 Statistik Deskriptif Variabel Penelitian

Sumber: Data diproses dengan SPSS 24

Dari hasil regresi kita mendapatkan persamaan regresi linier berganda sebagai berikut:

$$
\begin{aligned}
\text { SQRTROE }= & 0,667-4,670 E \\
& -7 S Q R T P D B \\
& -0,016 S Q R T \text { Inflasi } \\
& +e
\end{aligned}
$$

Berdasarkan tabel di atas menunjukkan bahwa jumlah data yang digunakan dalam penelitian ini adalah 120 sampel data yang diambil dari laporan keuangan tahunan di Bursa Efek Indonesia pada tahun 2014-2017. Dari tabel data di atas hasil penelitian menunjukkan bahwa:

1. Variabel PDB tidak secara signifikan mempengaruhi ROE ke arah negatif.

2. Variabel inflasi tidak secara signifikan mempengaruhi ROE ke arah negatif.

\section{Pembahasan Penelitian}


Dalam studi ini, PDB tidak memiliki pengaruh signifikan terhadap profitabilitas dan memiliki arah negatif.

PDB tidak berpengaruh signifikan terhadap kinerja perusahaan. Secara bersamaan, inflasi, suku bunga, dan PDB berpengaruh signifikan terhadap kinerja perusahaan (Halim, 2013).

Peningkatan nilai PDB suatu negara menunjukkan peningkatan kesejahteraan rakyatnya, dan ini tentunya akan berdampak pada peningkatan permintaan agregat, dan itu harus diimbangi dengan pertumbuhan ekonomi di sektor riil, peningkatan kesejahteraan rakyat tentu akan diikuti oleh peningkatan tabungan masyarakat di bank, dan ini akan memiliki efek positif pada pendapatan bank, yang akan meningkatkan pengembalian aset bank.

Pengujian variabel inflasi menunjukkan bahwa tidak ada pengaruh yang signifikan terhadap profitabilitas dan memiliki arah negatif.

Riaz, (2013), dan Sultoni, (2014) mengemukakan bahwa CPI memiliki hubungan negatif dengan ROE.

Hasil penelitian yang dilakukan oleh Vejzagic \& Zarafat, (2014) mengungkapkan bahwa dalam kasus di Malaysia, inflasi (CPI) tidak signifikan untuk rata-rata semua bank dan Maybank.

Jika tingkat inflasi diantisipasi, bank dapat menyesuaikan tingkat bunga untuk meningkatkan pendapatan dari pengeluaran.
Sebaliknya, jika tingkat inflasi tidak diantisipasi, bank tidak dapat melakukan penyesuaian yang tepat dari suku bunga dan biaya dapat meningkat lebih cepat daripada pendapatan (Alper, 2017).

Penelitian oleh Wibowo, (2013) dan Sultoni, (2014) menyimpulkan bahwa variabel inflasi tidak secara signifikan mempengaruhi profitabilitas bank umum syariah di Indonesia.

Hasil penelitian ini menunjukkan bahwa tingkat inflasi tidak memiliki pengaruh negatif yang signifikan terhadap profitabilitas bank. Meningkatnya inflasi dapat meningkatkan pendapatan dan biaya operasional, dan sebaliknya. Dengan demikian peningkatan pendapatan yang dapat dinikmati bank lebih rendah dari biaya yang dikeluarkan sehingga profitabilitasnya menurun. Rendahnya profitabilitas yang diperoleh bank menggambarkan rendahnya nilai ROE sehingga menunjukkan bahwa kinerja keuangan bank mengalami penurunan karena bank tidak dapat menghasilkan laba dengan modal mereka. Ketika inflasi meningkat, BI akan menaikkan suku bunga yang akan mempengaruhi biaya modal yang harus ditanggung oleh bank, menghasilkan penurunan laba bank yang pada akhirnya akan membuat nilai rasio ROE akan menjadi kecil.

\section{Kesimpulan}


Berdasarkan hasil uji asumsi klasik menyatakan bahwa tidak ada masalah dengan data yang digunakan dalam penelitian. Kemudian berdasarkan hasil pengujian koefisien determinasi (R2) menghasilkan nilai 13 persen, yang berarti bahwa variabel independen yang digunakan dalam model memiliki kemampuan menjelaskan variabel dependen sebesar 13 persen. Selanjutnya, uji F, dalam penelitian ini menghasilkan nilai 0,464 yang berada di atas 0,05 (lima persen). Dengan kata lain, variabel independen mencakup PDB, dan inflasi simultan tidak memiliki pengaruh signifikan terhadap variabel dependen dalam bentuk ROE. Sedangkan secara parsial, berdasarkan uji-t, variabel PDB, dan inflasi memiliki pengaruh negatif dan tidak signifikan terhadap ROE. Penelitian ini juga memiliki keterbatasan dalam menentukan sampel mana yang masih menggunakan purposive sampling sehingga dalam penelitian selanjutnya diharapkan menggunakan teknik pengambilan sampel lain seperti random sampling untuk menganalisis faktor-faktor apa yang mempengaruhi profitabilitas.

\section{Referensi}

Abdul Halim. (2013). Analisis Investasi (Edisi Pert). Jakarta: Salemba Empat.

Agus Widarjono, P. D. (2013). EKONOMETRIKA PENGANTAR DAN APLIKASINYA DISERTAI
PANDUAN EVIEWS.

Yogyakarta: UPP STIM YKPN.

Attar, D., Islahuddin, \& dan Shabri,

M. (2014). Pengaruh

Penerapan Manajemen Risiko

Terhadap Kinerja Keuangan

Perbankan yang Terdaftar di

Bursa Efek Indonesia. 3(1), 10-

20.

https://doi.org/10.13140/RG.2.1 .3589 .4882

Deger Alper, A. A. (2017). Bank Specific and Macroeconomic Determinants of Commercial Bank Profitability: Empirical Evidence from Nigeria. International Journal of Finance \& Banking Studies (2147-4486), 6(1), 25. https://doi.org/10.20525/ijfbs.v6 i1.627

Dr. M. Natsir, S.E., M. S. (2014).

Ekonomi Moneter Dan

Kebanksentralan (1st ed.). Jakarta: Mitra Wacana Media.

Edhi Satriyo Wibowo, M. S. (2013). ANALISIS PENGARUH SUKU BUNGA, INFLASI, CAR, BOPO, NPF TERHADAP PROFITABILITAS BANK SYARIAH. Diponegoro

Journal of Management, 2(2), 1-10. Retrieved from http://www.ncbi.nlm.nih.gov/pu bmed/14371128

Hasan, N. A., Shaari, N. A., Palanimally, Y. R., Kumar, R., \& Haji, M. (2013). the Impact of Macroeconomic and Bank Specific. Interdisciplinary Journal of Contemporary Research In Business, 5, 
2(2013), 106-126.

Hasan Sultoni. (2014). FAKTOR-

FAKTOR PENENTU

TINGKAT PROFITABILITAS

BANK UMUM SYARIAH DI

INDONESIA. Eksyar, 01(01), 41-52.

Iskandar Putong. (2015).

ECONOMICS : Pengantar

Ekonomi Mikro dan Makro.

Retrieved from

https://books.google.co.id/books

?id=WbMjBgAAQBAJ\&printse

$\mathrm{c}=$ frontcover $\& \mathrm{hl}=\mathrm{id} \# \mathrm{v}=$ onepage

$\& \mathrm{q} \& \mathrm{f}=$ false

Lawrence J. Gitman, C. J. Z. (2015).

Principles of Managerial

Finance (14th Editi). Retrieved from

https://www.pearson.com/us/hig her-education/product/Gitman-

Principles-of-Managerial-

Finance-14th-

Edition/9780133507690.html

Obamuyi, T. M. (2013). OKUNDU

HIZLI_02.03.2018_Determinan ts of Banks'Profitability in a

Developing Economy: Evidence From Nigeria. Organizations and Markets in Emerging Economies, 4(2), 97-111.

Retrieved from

http://search.ebscohost.com/logi n. aspx?direct=true \&profile=eho st\&scope $=$ site $\&$ authtype $=$ crawl er\&jrnl=20294581\&AN=93247 337\&h=YC1VQ8hPUtxprL5rR 3WDUG0m56QptBf8zjyJveriI/ 8CIXu9yQk1J/Y/BBg+rOcozkF NsZA79bAd/7C5yiO9aw $==\& c r$ $\mathrm{l}=\mathrm{c}$

Ogunbiyi, S. S., \& Ihejirika, P. O. (2014). Interest Rates and
Deposit Money Banks'

Profitability Nexus : The

Nigerian Experience. Oman

Chapter of Arabian Journal of

Business and Management

Review, 3(11), 133-148. https://doi.org/10.12816/001652 5

Pereira Garmendia, D. W. (2012). Inflation, Real Stock Prices and Earnings: Friedman Was Right. SSRN Electronic Journal, (October). https://doi.org/10.2139/ssrn.180 2431

Samina Riaz, A. M. (2013). Impact of Bank Specific and Macroeconomic Variables on the Performance of Commercial Banks of Nepal. The Romanian Economic Journal, Year XVI(47), 91-110. Retrieved from http://www.rejournal.eu/sites/rej ournal.versatech.ro/files/articole /2013-03-01/1935/riaz.pdf

Sukirno, S. (2011). Teori Pengantar Makroekonomi. Jakarta: PT. RajaGrafindo Persada.

Suryani, A., Suhadak, S., \& Hidayat, R. (2016). PENGARUH RASIO CAPITAL ADEQUACY

RATIO, BIAYA OPERASIONAL PER

PENDAPATAN OPERASIONAL, LOAN TO DEPOSIT RATIO, NET INTEREST MARGIN DAN NON PERFORMING LOAN TERHADAP RETURN ON ASSETS (Studi pada Bank Umum yang Terdaftar di Bursa Efek Indonesia Periode 2012-2. Jurnal Administrasi Bisnis S1 
Universitas Brawijaya, 33(1), 105-113.

Taswan. (2010). Manajemen

Perbankan (Edisi II).

Yogyakarta: UPP STIM YKPN.

Vejzagic, M., \& Zarafat, H. (2014).

An Ananlysis Of

Macroeconomic Determinants

Of Commercial Banks

Profitability In Malaysia For

Ther Period 1995-2011. Asian

Economic and Financial

Review, 4(41), 41-5741.

https://doi.org/10.1108/1755417

1211252565

Widyaningrum, L., \& Siswantoro, D. (2015). Analysis the Effect of Macroeconomic Indicators and Specific-Firm Characteristic as Determinant Profitability of Islamic Banks in Asia. Global Review of Islamic Economics and Business, 2(2), 085. https://doi.org/10.14421/grieb.2 014.022-01

Zvi Bodie. (2014). INVESTMENTS (10th Editi). Boston University, Alex Kane, University of California, San Diego, Alan J. Marcus: Boston College. 